OPEN ACCESS

Edited by:

Jian Sun,

Institute of Tibetan Plateau Research

(CAS), China

Reviewed by:

Dima Chen,

China Three Gorges University, China

Changliang Shao,

Chinese Academy of Agricultural

Sciences (CAAS), China

*Correspondence:

Hongfeng Bian

bianhf108@nenu.edu.cn

Nianpeng $\mathrm{He}$

henp@igsnrr.ac.cn

Specialty section:

This article was submitted to

Conservation and Restoration

Ecology,

a section of the journal

Frontiers in Ecology and Evolution

Received: 27 February 2021

Accepted: 26 April 2021

Published: 26 May 2021

Citation:

Jiang Z, Bian H, Xu L, Li M and

He N (2021) Pulse Effect of Precipitation: Spatial Patterns and Mechanisms of Soil Carbon

Emissions.

Front. Ecol. Evol. 9:673310. doi: 10.3389/fevo.2021.673310

\section{Pulse Effect of Precipitation: Spatial Patterns and Mechanisms of Soil Carbon Emissions}

\author{
Zhaoxia Jiang ${ }^{1}$, Hongfeng Bian ${ }^{1 *}$, Li X $\mathrm{Xu}^{2}$, Mingxu $\mathrm{Li}^{2}$ and Nianpeng He $\mathrm{e}^{2,3,4 *}$ \\ 'State Environmental Protection Key Laboratory of Wetland Ecology and Vegetation Restoration, School of Environment, \\ Northeast Normal University, Changchun, China, ${ }^{2}$ Institute of Geographic Sciences and Natural Resources Research, \\ Chinese Academy of Sciences, Beijing, China, ${ }^{3}$ College of Resources and Environment, University of Chinese Academy \\ of Sciences, Beijing, China, ${ }^{4}$ Key Laboratory of Vegetation Ecology, Ministry of Education, Institute of Grassland Science, \\ Northeast Normal University, Changchun, China
}

The rapid and strong release of $\mathrm{CO}_{2}$ caused by precipitation (known as the pulse effect) is a common phenomenon that significantly affects ecosystem $\mathrm{C}$ cycling. However, the degree to which the pulse effect occurs overlarge regional scales remains unclear. In this study, we conducted continuous and high-frequency measurements of soil $\mathrm{CO}_{2}$ release rates $\left(R_{S}\right)$ for $48 \mathrm{~h}$ after simulated precipitation, along a precipitation gradient of different grassland types (i.e., meadow, typical, and desert) in Inner Mongolia, China. Pulse effects were assessed using the maximum $R_{S}\left(R_{\text {soil-max }}\right)$ and accumulated $\mathrm{CO}_{2}$ emissions $\left(A_{R s-s o i l}\right)$. Strong precipitation pulse effects were found in all sites; however, the effects differed among grassland types. In addition, an apparent decrease in both $R_{\text {soil-max }}$ and $A_{R s-s o i l}$ was observed from the east to west, i.e., along the decreasing precipitation gradient. $A_{R s-s o i l}$ values followed the order: temperate meadow grassland $\left(0.097 \mathrm{mg} \mathrm{C} \mathrm{g}^{-1}\right.$ soil) > typical temperate grassland $\left(0.081 \mathrm{mg} \mathrm{C} \mathrm{g}^{-1}\right.$ soil) > temperate desert grassland $\left(0.040 \mathrm{mg} \mathrm{C} \mathrm{g}^{-1}\right.$ soil). Furthermore, $R_{\text {soil-max }}$ and $A_{R s-s o i l}$ were significantly positively correlated with soil quality (SOC, POC, and $\mathrm{N}$, etc.; $P<0.01)$. $A_{R s-s o i l}(P<0.05)$ and $A_{R s-S O C}(P<0.01)$ were significantly affected. $A_{R s-s o i l}$ and $A_{R S-S O C}$ were also positively correlated with soil microbial biomass significantly $(P<0.05)$. $R_{\text {soil-max }}$ and $A_{R s-s o i l}$ had similar spatial variations and controlling mechanisms. These results greatly support the substrate supply hypothesis for the effects of precipitation pulses, and provide valuable information for predicting $\mathrm{CO}_{2}$ emissions. Our findings also verified the significant effect of soil $\mathrm{CO}_{2}$ release from precipitation pulses on the grasslands of arid and semi-arid regions. Our data provide a scientific basis for model simulations to better predict the responses of ecosystem carbon cycles in arid and semi-arid regions under predicted climate change scenarios.

\section{Keywords: carbon cycle, soil organic matter, decomposition, precipitation gradient, pulse effect, grassland}

\footnotetext{
Abbreviations: WHC, water holding capacity; $R_{s}$, soil respiration rate; $R_{\text {soil-max }}$, soil maximum respiration rate; $A_{R s-s o i l}$, accumulative emission of $\mathrm{CO}_{2}$ on soil; $A_{R s-S O C}$, accumulative emission of $\mathrm{CO}_{2}$ on SOC; SOC, soil organic carbon; POC, particulate organic carbon; EOC, easily oxidizable organic carbon.
} 


\section{HIGHLIGHTS}

- $\mathrm{CO}_{2}$ release due to precipitation pulses significantly affects the carbon cycle.

- High-frequency soil $\mathrm{CO}_{2}$ release rate measurements were recorded after precipitation.

- The precipitation pulse effect was strong and differed among grassland types.

- Peak release rates and accumulated $\mathrm{CO}_{2}$ were positively correlated with soil quality.

- Our data improve model predictions of soil $\mathrm{CO}_{2}$ release from the pulse effect.

\section{INTRODUCTION}

The soil C pool is the largest global C reservoir and it plays an important role in the $\mathrm{C}$ cycle of ecosystems. The decomposition of soil organic matter (SOM) is an important pathway for $\mathrm{CO}_{2}$ gas exchange between the soil environment and the atmosphere (Barnard et al., 2013). SOM is one of the most important components of soils because it improves soil physical, chemical, and biological properties (Liu et al., 2011). Furthermore, the decomposition of SOM is the main energy source for the physiological activities of soil microorganisms. Recently, the composition, properties, and conversion of SOM have become important topics of research. As an indispensable process in the ecosystem C cycle, the decomposition of SOM may directly affect climate change at regional or global scales (Mayes et al., 2012).

Soil organic matter decomposition is a common process whereby soil microorganisms decompose organic matter and release a large amount of $\mathrm{CO}_{2}$. The rate of SOM decomposition is important for the soil $\mathrm{C}$ cycle and its response to future effects of climate change (Schlesinger and Andrews, 2000). Many studies have been conducted to assess SOM decomposition along horizontal and vertical transects in different areas (Craine et al., 2012) and to clarify the main influential factors and underlying mechanisms involved in SOM decomposition (Wu and Brookes, 2005). The factors that influence SOM decomposition, such as temperature, precipitation, soil microbes, and soil aggregates, differ among different ecosystems (Müller and Höper, 2004). For example, soil moisture, which is largely related to precipitation, has been shown to significantly affect the SOM decomposition rate in field and laboratory experiments (Austin et al., 2004). In natural ecosystems, soil moisture is regulated mainly by precipitation events, which commonly cause a rapid release of $\mathrm{CO}_{2}$ from the soil environment within a short period. This rapid, precipitation-driven release of $\mathrm{CO}_{2}$, known as the pulse effect or birch effect (Birch, 1958), has been estimated to account for approximately one-fifth of the total $\mathrm{CO}_{2}$ released from soil C pools (Moyano et al., 2013; Liu et al., 2018). Overall, precipitation pulse effects are relatively stronger in arid and semiarid regions (Austin et al., 2004; Esch et al., 2016). Therefore, it is important to understand the differences and variations in the responses of SOM decomposition to precipitation pulses in different steppe types. Elucidating the factors that influence the process of the precipitation pulse effect, will improve understanding of grassland SOM stability and thus enable highly accurate predictions.

Precipitation is one of the main controlling factors for the interannual variation in the productivity, soil respiration, and biogeochemical cycles of the temperate grasslands of China (Nielsen and Ball, 2015; Ni et al., 2019). Water is a stress factor in the Inner Mongolia Plateau (Bai et al., 2008). The frequency and intensity of precipitation over the grasslands of Inner Mongolia have shown an increasing trend over the last 60 years, indicating that more precipitation pulse events are likely to occur (Song et al., 2017). These arid and semiarid regions commonly show different levels of pulse responses owing to changes in rainfall frequency and rainfall intensity (Nielsen and Ball, 2015). Microbial respiration shows very sharp responses to precipitation events and may reach peak levels within several minutes (Wang et al., 2016a). Soil microorganisms rapidly assimilate available organic matter under higher soil moisture levels, resulting in a higher degree of $\mathrm{CO}_{2}$ release. The response of soil microorganisms to increasing soil moisture is also related to the duration of drought before soil rewetting by precipitation. To understand the effect of precipitation pulses on soil carbon pools in the grasslands of Inner Mongolia, we investigated indicators, such as soil substrate, soil grain size and soil microorganisms, as mentioned previously, for relevant analyses. Commonly, long periods of drought may increase the utilization efficiency of soil to available SOM after a precipitation event. In arid and semi-arid regions, the low soil moisture level is often a stress factor for SOM decomposition (Wu and Brookes, 2005). Precipitation, which causes a rapid change in soil moisture, is an important driving factor for the structure and function of the soil C cycle in arid and semi-arid regions (Moyano et al., 2013). The frequency and intensity of precipitation may affect the activities of microorganisms. Soil aggregate damage and matrix desorption may occur under drought conditions, which may consequently increase the available substrate matrix and increase the hydrophobicity of soils with high levels of SOM (Mikha et al., 2005). When precipitation occurs, microbial drought stress is relieved, and the available substrate preserved under the drought conditions can be rapidly utilized by microbes, resulting in the release of a large amount of $\mathrm{CO}_{2}$ into the atmosphere (Xiang et al., 2008).

The underlying mechanisms involved in the precipitation pulse effect remain unclear because most previous studies used the absorption method or conducted meteorological chromatography at intervals of hours or days. Furthermore, it is unclear how and why the precipitation pulse effect varies at large regional scales. Here, we conducted continuous and highfrequency measurements (total $n=138$ ) of the soil $\mathrm{CO}_{2}$ release rate $\left(R_{s}\right)$ for $48 \mathrm{~h}$ after simulated precipitation events at 10 sites along a precipitation gradient transect of different grassland types (i.e., meadow, typical, and desert) in Inner Mongolia, northern China. The precipitation pulse effects were assessed using the maximum $R_{s}$ values $\left(R_{\text {soil-max }}\right)$ and accumulated $\mathrm{CO}_{2}$ emissions $\left(A_{R s-s o i l}\right)$ (Figure 1). Our study addressed the knowledge gap regarding the short-term effects of precipitation pulses on a regional scale. Our findings may help to identify the differences and influential factors of precipitation pulse effects in 


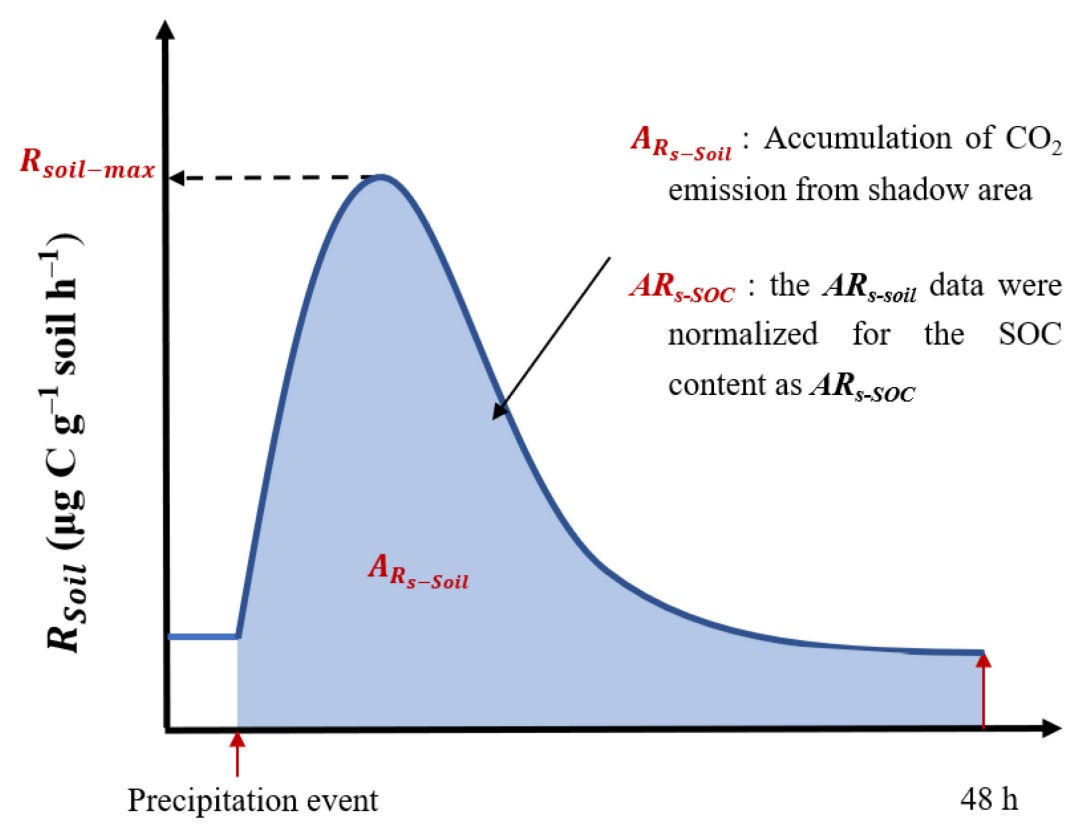

Time (h)

FIGURE 1 | Example of a pulse effect (soil $\mathrm{CO}_{2}$ emissions) in response to a simulated precipitation event. Precipitation event stand pulse precipitation; Time (h) represents the duration of the precipitation pulse effect; $48 \mathrm{~h}$ represents $48 \mathrm{~h}$ after of precipitation pulse occurrence. $R_{\text {soil }}$, soil respiration rate; $R_{\text {soil }-m a x}$, soil maximum respiration rate.

steppe environments. It was hypothesized that the soil substrates, physic-chemical properties, and soil microbes would influence the effect of precipitation pulses (i.e., substrate supply mechanism of microbes vs. stress mechanism). This study provides a full scientific basis for the exchange of $\mathrm{CO}_{2}$ between the soil and the atmosphere in temperate steppe environments, which may help to develop model predictions regarding the processes involved in such short-term but large $\mathrm{CO}_{2}$ release events.

\section{MATERIALS AND METHODS}

\section{Study Area and Soil Sampling}

Grasslands in China account for $12 \%$ of the total grasslands worldwide and are mainly distributed in arid and semiarid regions (Fang et al., 2010). Furthermore, the grasslands of the Inner Mongolia Plateau, located within the Eurasian continent, cover half of the total land area in China and are classified as temperate grasslands (or steppe) (Kang et al., 2007). In this study, we constructed 10 sampling sites from the northeast to the southwest of the study area, located in the Northeast Forested Steppe Sample Zone (NECT) of China The International Geosphere-Biosphere Program $\left(112.15-123.51^{\circ} \mathrm{E}\right.$, $\left.43.55-45.11^{\circ} \mathrm{N}\right)$, as the 14 th transect of The International Geosphere-Biosphere Program, namely the Northeast China Transect (Koch, 1995). The mean annual temperature of the transected area ranged from 0.11 to $5.79^{\circ} \mathrm{C}$, and the mean annual precipitation varied from 150 to $400 \mathrm{~mm}$, of which $70 \%$ occurred from June to August. The 10 sampling sites transected three main grassland types: meadow steppe, typical steppe, and desert steppe (Figure 2 and Supplementary Table 1).

Along the transect, the soil type was mainly prairie soil with a typical calcium profile. From east to west, the soil type was black calcareous soil, dark chestnut calcareous soil, typical chestnut calcareous soil, sandy gravel desert soil, and gray desert soil, gray calcareous soil. The northeast and southwest areas represents semi-humid to semi-arid and arid climate regions, respectively. The dominant species of the meadow steppe were Leymus chinensis (Trin.) Tzvel. and Stipa grandis P.A. Smirn. The dominant species of the typical steppe were Cleistogenes squarrosa (Trin.) Keng., Agropyron cristatum (L.) Gaertn., and Artemisia frigida Willd. The dominant species in the desert grasslands were S. capillata Linn., Allium polyrhizum Turcz., Hippolytia trifida (Turcz.) Poljak., and Salsola collina Pall. (Cao et al., 2010).

Soil samples were collected in early August 2018. In each site, we constructed four plots $(1 \times 1 \mathrm{~m})$ at $20 \mathrm{~m}$ apart, along a $100 \mathrm{~m}$ transect line. After surveying the plant community and manually removing the soil surface litter, we used a soil drill to collect $\sim 2.5 \mathrm{~kg}$ of $0-10 \mathrm{~cm}$ soil in each plot. In the laboratory, all visible roots and large stones were manually removed from the samples, and samples were stored in a refrigerator at $4^{\circ} \mathrm{C}$ prior to determination of the microbial biomass. The remaining soil samples were air-dried, passed through a $2 \mathrm{~mm}$ sieve, and then stored until measurement of the total C (Najera et al., 2020), total nitrogen (TN), organic C (SOC), soil particulate organic C, and other parameters (He et al., 2009). 


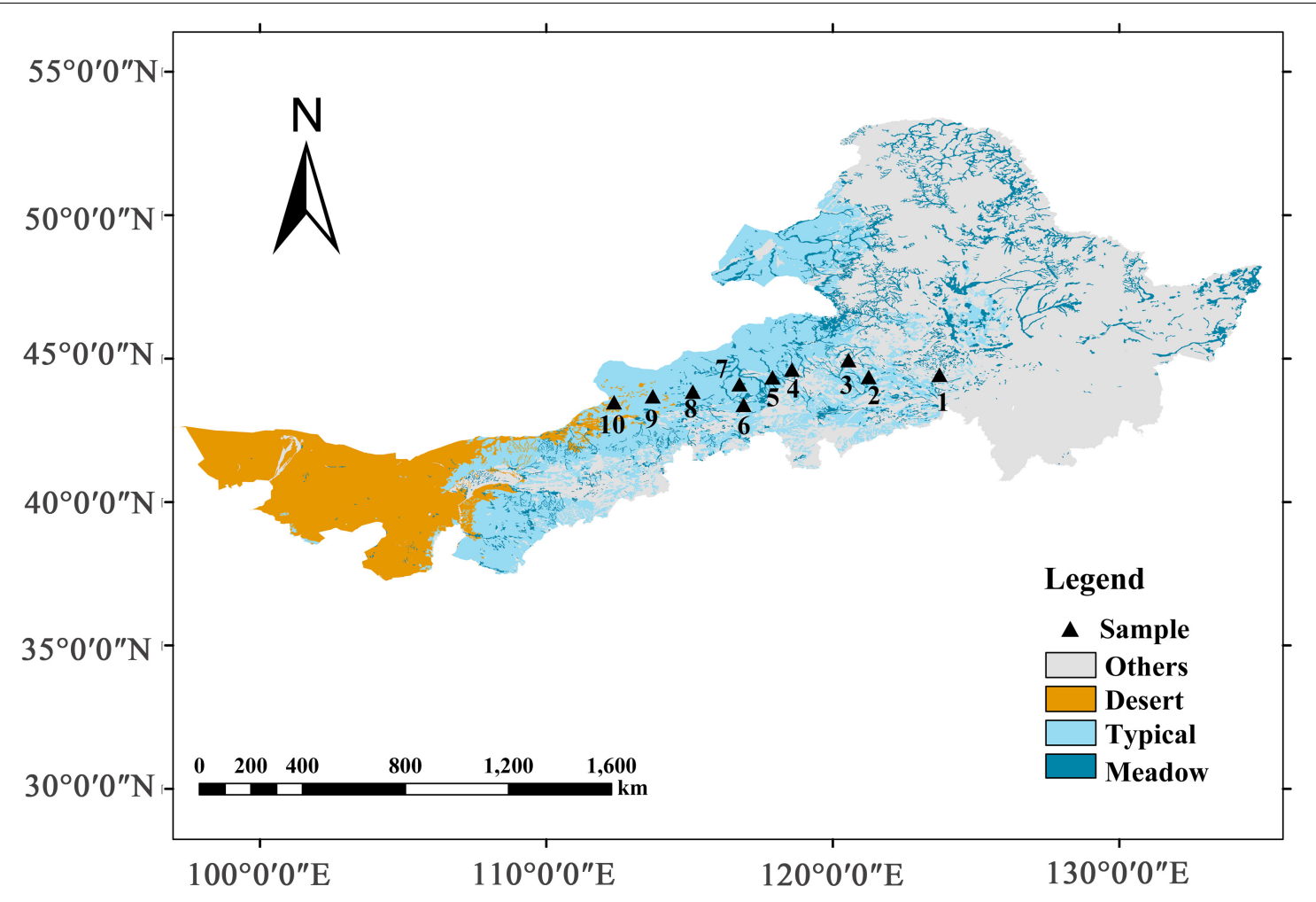

FIGURE 2 | Locations of field investigations along a north-east grassland transect in Inner Mongolia, China. Sampling sites were positioned along a precipitation gradient from east to west, which included three types of grasslands: meadow grassland (1-3), typical grassland (4-7), and desert grassland (8-10).

Soil $\mathrm{pH}$, soil oxidation-reduction potential (ORP), and soil electrical conductivity were measured in air-dried soil samples mixed in a 1:2.5 (v/v) soil: water ratio, using an Ultrameter-2 pH meter (Myron L. Company, Carlsbad, CA, United States). Soil texture was measured using a particle analyzer (Mastersizer 2000, Malvern, Worcestershire, England) after the organic matter and carbonates were removed with $30 \%$ hydrogen peroxide and 30\% hydrochloric acid, respectively. Soil TN concentrations were measured using an elemental analyzer (Vario EL $\varnothing$, Elementar, Germany). SOC was analyzed using the $\mathrm{H}_{2} \mathrm{SO}_{4}-\mathrm{K}_{2} \mathrm{Cr}_{2} \mathrm{O}_{7}$ oxidation method (Nelson and Sommers, 1982). Furthermore, the phospholipid fatty acid (PLFA) contents were determined using the mild alkaline methyl esterification method (Bååth and Anderson, 2003). The samples were analyzed using a Thermo ISQ gas-chromatography mass-spectrometry system (TRACE GC Ultra ISQ, Germany). The lipids were extracted from fresh soil samples (8 $\mathrm{g}$ of dry weight -equivalent) using a chloroform: methanol: phosphate buffer (1:2:0.5). The individual compounds were identified by comparing their relative retention times with 37 commercially available FAMEs (FAME 37 47885-U, Supelco Inc.) and a mixture of 26 bacterial FAMEs (BAME 26 47080-U, Supelco Inc.). The concentrations of the individual compounds were calculated by comparing their peaks with an internal standard (nonadecanoic acid methyl ester 19:0). The sum of all PLFAs was used to represent the viable microbial biomass.

\section{Measurement of the Soil Respiration Rate}

Soil samples used in the incubation experiments were air-dried in a room at $20^{\circ} \mathrm{C}$ for $\sim 1$ week until the soil water content reached $<10 \%$ of WHC (water holding capacity). We measured the WHC using a simple substitute for the soil core method (He et al., 2013). Before the experiment, subsamples (30 g) were placed in incubation bottles $(5 \mathrm{~cm}$ diameter, $10 \mathrm{~cm}$ height), with five replicates per site and the microbial respiration rate $\left(R_{s}\right)$ of the dry soil was recorded using a measuring device. The air-dried soil samples were then rewetted to $65 \%$ WHC of the soil sample point using a sprayer to simulate a precipitation event and maintained at a constant temperature of $20^{\circ} \mathrm{C}$. The soil respiration rate $\left(R_{S}\right)$ was then measured over $48 \mathrm{~h}$ (Wang et al., 2016a). In practice, $R_{s}$ was continuously measured using equipment developed by He et al. (2013). This system enabled us to collect $R_{s}$ measurements at a high frequency (Liu et al., 2018). The dynamics of $R_{s}$ for each replicate were measured at intervals of $21 \mathrm{~min}$ during the $48 \mathrm{~h}$ incubation period. The $R_{s}\left(\mathrm{mg} \mathrm{C} \mathrm{g}^{-1}\right.$ soil $\mathrm{h}^{-1}$ ) was calculated based on the slope of the change in the $\mathrm{CO}_{2}$ concentration and conversion factors (He et al., 2013), as follows:

$$
R_{s}=(C \times V \times \alpha \times \beta) / m
$$

Where $C$ is the slope of the change in $\mathrm{CO}_{2}$ concentration, $V$ is the volume of the incubation bottle and gas tube, $\alpha$ is the conversion 
coefficient for $\mathrm{CO}_{2}$ mass, $\beta$ is a conversion coefficient of time, and $m$ is the soil weight (g).

\section{The Pulse Effect of Precipitation on Soil $\mathrm{CO}_{2}$ Release}

In this study, three indicators (as shown in Figure 1) were selected to describe the process of the pulse effect of soil $\mathrm{CO}_{2}$ released after a precipitation event, namely $R_{\text {soil-max }}, A_{R s-\text { soil }}$, and $A_{R s-S O C}$.

We chose the maximum value of soil respiration rate reached in the pulse effect of precipitation as $R_{\text {soil-max }}$. That is, $R_{\text {soil-max }}$ : represents soil maximum respiration rate.

To characterize the total pulse effect, the accumulative emission of $\mathrm{CO}_{2}$ during the $48 \mathrm{~h}$ incubation period was calculated relative to the soil mass $\left(A_{R s-s o i l}, \mathrm{mg} \mathrm{C}^{-1}\right.$ soil) as follows:

$$
A_{R_{s-S o i l}}=\frac{\sum_{i}^{48} \frac{R_{S-t_{i}}+R_{S-t_{i+1}}}{2} \times\left(t_{i+1}-t_{i}\right)}{m},
$$

Where $t_{i}$ and $t_{i+1}$ are different measurement times (h).

To further explore the response mechanisms of soil microbes after a precipitation event, the $A_{R s-s o i l}$ data were normalized for the SOC content as $A_{R s-S O C}$ (mg C g ${ }^{-1}$ soil), as follows:

$$
A_{R_{s-\mathrm{SOC}}}=\frac{\sum_{i}^{48} \frac{R_{S-t_{i}}+R_{S-t_{i+1}}}{2} \times\left(t_{i+1}-t_{i}\right)}{m^{\times} c} .
$$

\section{Statistical Analysis}

The normality of the data was evaluated using the KolmogorovSmirnov test. Differences in $A_{R s-s o i l}$ and $A_{R s-S O C}$ among the different grassland types were assessed using a one-way analysis of variance, with the least significant differences test. Correlation and regression analyses were used to determine the relationship between the influential factors and $A_{R s-s o i l}$ and $A_{R s-S O C}$. RDA analysis was used to explore the relative contribution of the influential factors (climate, soil properties, and microbes) and their interaction with the pulse effect by Canoco 5.0. Other statistical tests were performed using IBM SPSS Statistics 19.0 statistical software, with $P$-values $<0.05$ indicating significant differences.

\section{RESULTS}

\section{Changes in the Precipitation Pulse Effect Among Different Grassland Soils}

All grassland soils showed a strong precipitation pulse effect on the soil $\mathrm{CO}_{2}$ release after several to $10 \mathrm{~min}$, resulting in the release of a large amount of $\mathrm{CO}_{2}$ into the atmosphere (Figure 3). The accumulated amount of $\mathrm{CO}_{2}$ released within $48 \mathrm{~h}\left(A_{R s-s o i l}\right.$, Figure 3A) after a simulated precipitation event differed significantly among different grassland types $(P<0.05)$ in the following order: temperate meadow steppe $\left(0.097 \mathrm{mg} \mathrm{C} \mathrm{g}^{-1}\right.$ soil $)>$ temperate typical steppe $\left(0.081 \mathrm{mg} \mathrm{C} \mathrm{g}^{-1}\right.$ soil) > temperate desert steppe ( $0.040 \mathrm{mg} \mathrm{C} \mathrm{g}^{-1}$ soil). However, after standardizing the data for the SOC content, the $A_{R s-S O C}$ findings were ordered as follows: temperate desert steppe
(9.08 $\mathrm{mg} \mathrm{C} \mathrm{g}^{-1}$ SOC) > temperate meadow steppe $(6.79 \mathrm{mg}$ $\mathrm{C} \mathrm{g}^{-1}$ SOC $)>$ temperate typical steppe $\left(4.95 \mathrm{mg} \mathrm{C} \mathrm{g}^{-1}\right.$ SOC) (Figure 3B).

\section{Influence of Soil Properties on $\boldsymbol{R}_{\text {soil-max }}$ and $A_{R s-\text { soil }}$}

Along the grassland transect, $R_{\text {soil-max }}$ increased with increasing soil C and nitrogen (N) contents (Figures 4C,D). In particular, $R_{\text {soil-max }}$ was closely related to soil particulate organic C (POC; Figure 4A) and easily oxidizable organic C (EOC; Figure 4B). The increase in soil POC and EOC contents significantly increased $R_{\text {soil-max }}$. The influence of soil properties on $R_{\text {soil-max }}$ was significant (Figure 5 and Supplementary Table 2).

Similarly, $A_{R s-s o i l}$ was significantly, linearly, and positively correlated with soil $\mathrm{C}$ and $\mathrm{N}$ contents (Figures 5, 6). During the $48 \mathrm{~h}$ incubation period, $A_{R s-s o i l}$ was negatively correlated $\left(P<0.05, R^{2}=0.43\right)$ with soil sand content (Figure 7A), but positively correlated with the soil clay and silt contents (Figures 7B,C). Other soil properties had significant effect on $A_{R s-s o i l}$ (Figure 5 and Supplementary Table 2). When we standardized $A_{R s-s o i l}$ to SOC content $A_{R s-S O C}$, there was a significant correlation between $A_{R s-S O C}$ and soil texture composition (Figure 7). $A_{R s-S O C}$ was significantly, linearly, and positively correlated with soil sand content $(P<0.01$, $R^{2}=0.70$; Figure 7), but negatively correlated with soil clay and silt contents.

\section{Relationship Between Soil Microbial Biomass and the Precipitation Pulse Effect}

Soil microbial biomass had an important effect on the amount of $\mathrm{CO}_{2}$ released during the simulated precipitation pulse events. A significant positive correlation was observed between $A_{R s-s o i l}$ and soil microbial biomass, i.e., $A_{R s-s o i l}$ increased with increasing soil bacterial and fungal biomass (Figure 8A). A significant negative correlation was observed between $A_{R s-S O C}$ and microbial biomass (Figure 8B). $A_{R s-S O C}$ gradually decreased along the transect with increasing microbial biomass.

\section{DISCUSSION}

\section{Soil $\mathrm{CO}_{2}$ Release in Semi-Arid Grasslands Responds Strongly to Precipitation Events}

This study demonstrated that precipitation had a strong pulse effect on the release of $\mathrm{CO}_{2}$ from the soil environment in temperate semi-arid steppe environments, i.e., precipitation events can result in large $\mathrm{CO}_{2}$ emissions (Figure 3). Soil $\mathrm{CO}_{2}$ released from precipitation pulses has been estimated to account for $\sim 20 \%$ of the total annual $\mathrm{CO}_{2}$ released from the soil (Göransson et al., 2013; Smith et al., 2017). This phenomenon may greatly affect soil $\mathrm{C}$ turnover rates in terrestrial ecosystems ( $\mathrm{Li}$ et al., 2018), and the infiltration of precipitation may displace the $\mathrm{CO}_{2}$ that was previously 

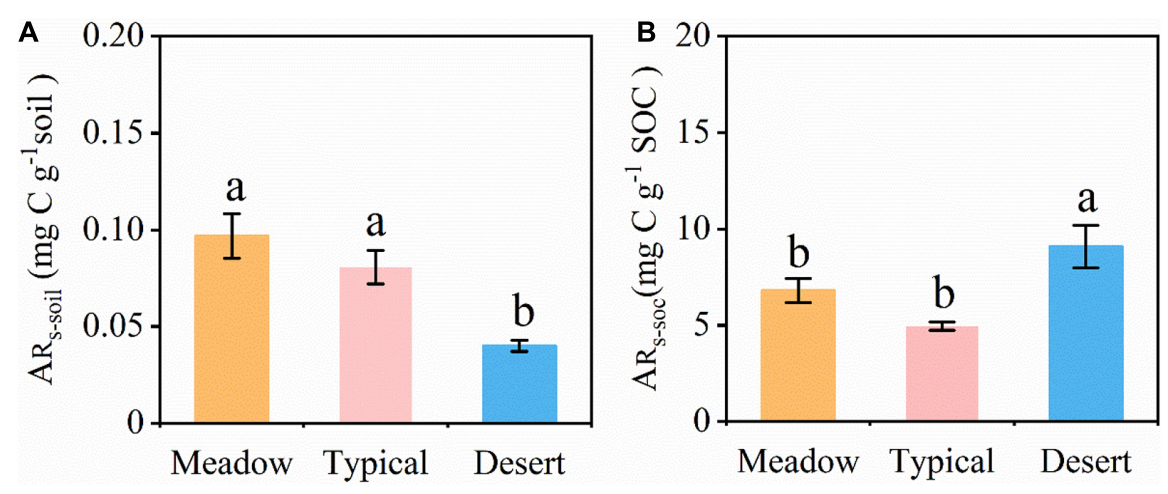

FIGURE 3 | (A) Accumulation of released soil $\mathrm{CO}_{2}\left(A_{R s-\text { soil }}\right)$ for $48 \mathrm{~h}$ after a simulated precipitation event. (B) $\mathrm{Accumulation}$ of released $\mathrm{SOC} \mathrm{CO}_{2}\left(A_{R s-S O C}\right)$ for $48 \mathrm{~h}$ after a simulated precipitation event. $A_{R s-\text { soil }}$ and $A_{R s-S O C}$ were calculated based on the soil and soil organic $\mathrm{C}$, respectively. $A_{R s-s o i l}$, accumulative emission of $\mathrm{CO}_{2}$ relative to soil mass; $A_{R s-S O C}$, accumulative emission of $\mathrm{CO}_{2}$ relative to SOC. Error bars represent SE (Meadow and Desert, $n=3 ;$ Typical, $n=4$ ). Different lowercase letters indicate significant differences at $P<0.05$.
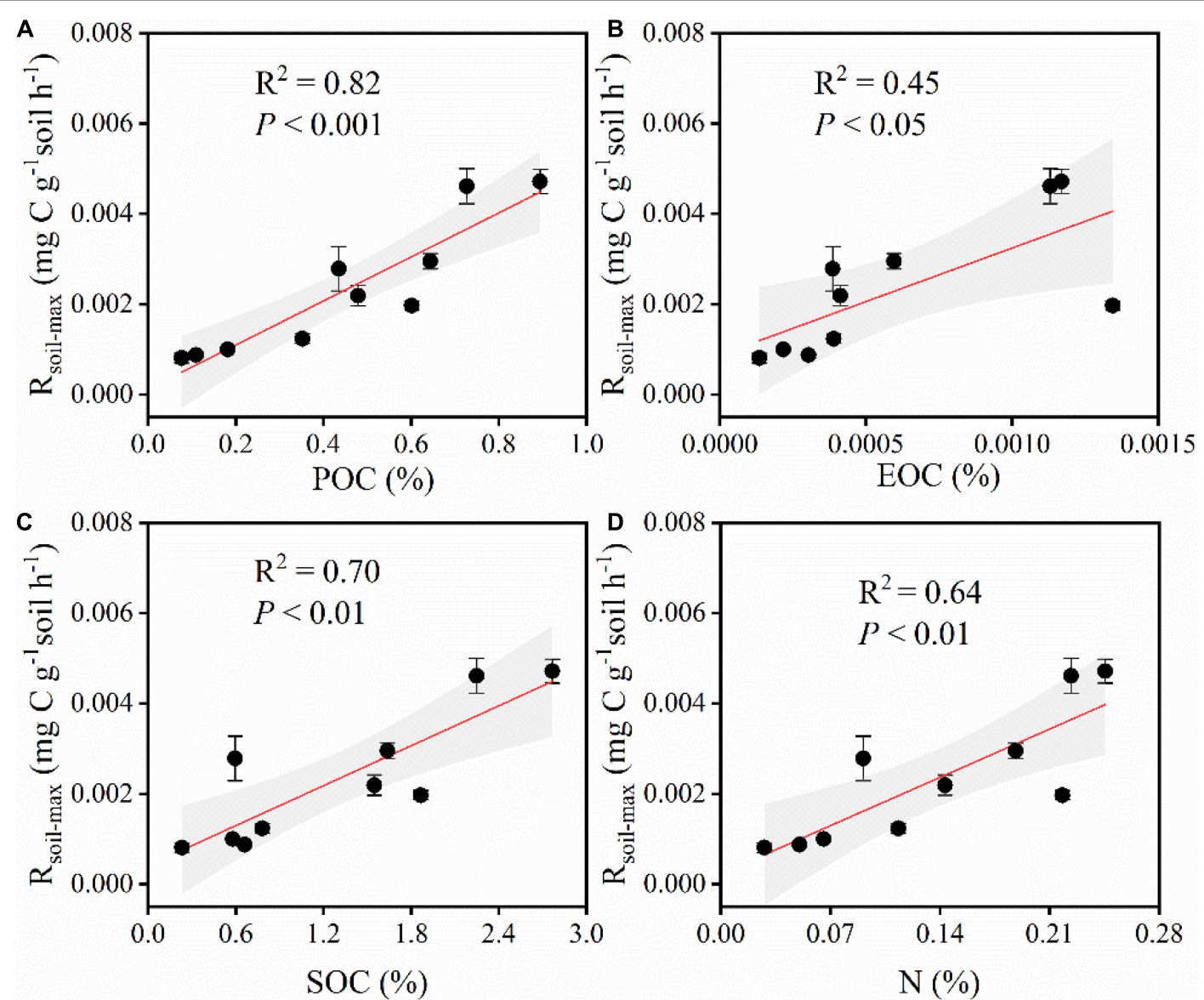

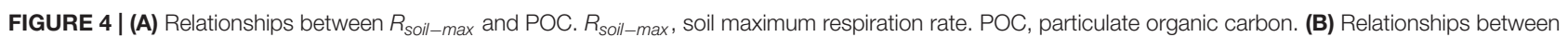
$R_{\text {soil-max }}$ and EOC. EOC, easily oxidizable organic carbon. (C) Relationships between $R_{\text {soil-max }}$ and SOC. SOC, soil organic carbon. (D) Relationships between $R_{\text {soil-max }}$ and N. N, total nitrogen. Shaded areas indicate the 95\% confidence interval and vertical bars denote SE.

accumulated in soil pores (Huxman et al., 2004b). The water displacement of soil pore space gas with high $\mathrm{CO}_{2}$ concentration is the fastest response. This process usually occurs within seconds or minutes of water addition, and may last up to a few hours. In a simulation, there was 15 times the $\mathrm{CO}_{2}$ efflux from the soil after a 4-h wet-up 


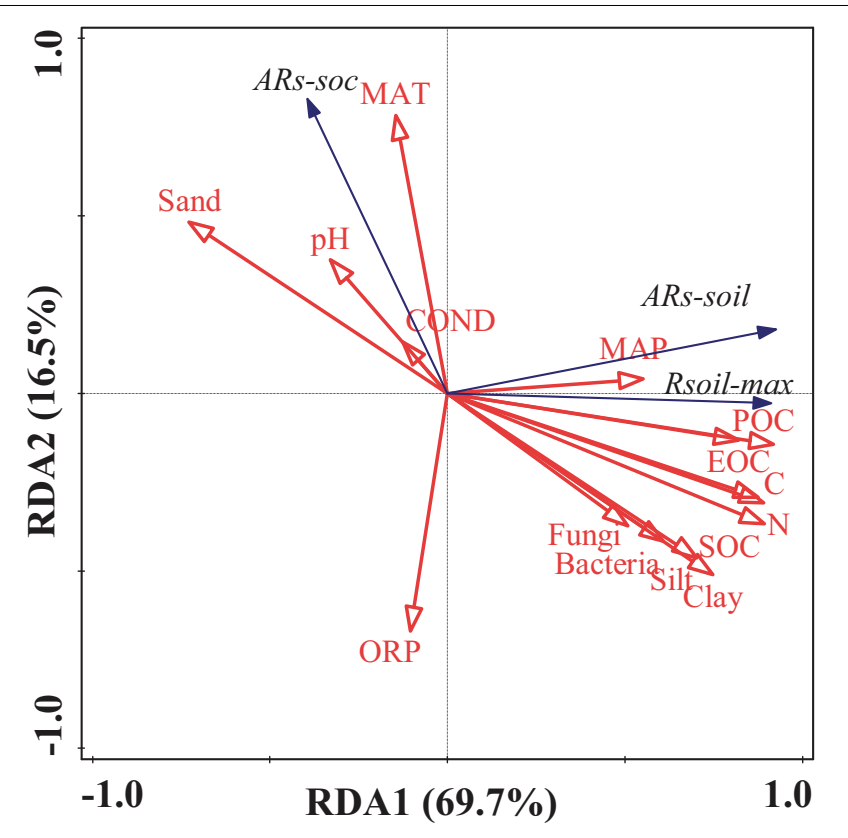

FIGURE 5 | Results of the redundancy analysis of the soil environmental factors and the soil microbial biomass. Blue arrows represent the response variables; red arrows represent the independent variables. $R_{\text {soil-max }}$, soil maximum respiration rate; $A_{R s-s o i l}$, accumulative emission of $\mathrm{CO}_{2}$ relative to soil mass; $A_{R s-S O C}$, accumulative emission of $\mathrm{CO}_{2}$ relative to $\mathrm{SOC}$; POC, particulate organic carbon; EOC, easily oxidizable organic carbon; SOC, soil organic carbon; $\mathrm{N}$, total nitrogen; $\mathrm{C}$, total carbon; $\mathrm{pH}$, potential of hydrogen; OPR, oxidation-reduction potential; COND, electrical conductivity.

in, but it only lasted $12 \mathrm{~min}$ (Chen et al., 2008). In this study, soil respiration was measured continuously for $48 \mathrm{~h}$ after the addition of water, so this transient $\mathrm{CO}_{2}$ emission was negligible. The microbial oxidation of labile SOM, which is available with the physical disruption of soil aggregates, may present one plausible explanation for the rapid release of $\mathrm{CO}_{2}$ after precipitation (Appel, 1998). Global climate models predict that annual precipitation in the mid-latitudes may increase in the future (i.e., by $10-20 \%$ ), and thus, further affect soil respiration in these regions (Fowler et al., 2013). Except for waterlogging, $R_{s}$ is generally positively correlated with soil moisture, especially in semi-arid ecosystems (Zhu et al., 2016).

In semi-arid steppe areas, precipitation may cause drastic fluctuations in soil moisture, and thus, result in dynamic $R_{s}$ responses. After precipitation, it is beneficial for soil microbes and soil enzymes to increase their activities (Stark and Firestone, 1995). Previous studies showed that $A_{R s-s o i l}$, after a simulated precipitation event, was approximately 2.2-3.7 times that of soils with consistent moisture levels (Esch et al., 2016). However, the influence of the precipitation pulse effect on $R_{s}$ is complex, because the precipitation pulse effect is dependent on, and thus, may differ among, different vegetation types, soil physical and chemical properties, soil water conditions before precipitation, soil microbial communities, and precipitation intensities and durations (Norton et al., 2008). For dry soils, precipitation can improve soil moisture and, thus, rapidly stimulate microbial activity within several minutes to several days (Cui et al., 2019). Precipitation has been shown to triple soil respiration rates in the tropical and semi-arid forests of northern Queensland, Australia during the dry season, and even enhance $R_{s}$ by 30 times (Jones and Murphy, 2007; Sponseller, 2007). Furthermore, controlled field experiments showed that precipitation events can stimulate a drastic increase in $R_{S}$ in high-altitude grasslands (Alba Gutiérrez-Girón et al., 2015; Xu et al., 20115). In summary, the effect of precipitation pulses on the release of $\mathrm{CO}_{2}$ from the soil environment is common among various ecosystems and is a fast and complex process that requires consideration in future model predictions (Davidson et al., 2000).

\section{Soil Properties Influence the Precipitation Pulse Effect}

The precipitation pulse effect, represented as $R_{\text {soil-max }}$ and $A_{R s-s o i l}$, was significantly positively related to soil quality, especially the content of SOC, POC, and N (Figure 4), which demonstrates their potential to predict such effects. Commonly, better soil substrates can maintain microbial activity for longer and, release more $\mathrm{CO}_{2}$ (Wang et al., 2010), supporting the substrate supply hypothesis. Similarly, under prolonged drought conditions, a stronger pulse effect after a larger precipitation event can result from larger available substrate levels owing to the destruction of soil aggregates (Appel, 1998; Denef et al., 2001). After precipitation, the increased soil moisture content enhances the diffusivity of easily decomposable SOM. At the same time, soil microbes that are no longer subjected to drought stress become active and quickly reproduce (Xu et al., 2004), which could explain the observed rapid increase in $R_{\text {soil-max }}$ in the present study. However, with increasing in time after a precipitation event, the easily decomposable SOM can be depleted, and $R_{s}$ gradually decreases to the same level as that prior to the precipitation event (Lee et al., 2002). This is consistent with our observations in the current experiments.

Within $48 \mathrm{~h}$ of the precipitation event, the $A_{R s-s o i l}$ was significantly positively correlated with important parameters of soil quality (Figure 6). Precipitation events may rapidly alter the soil water potential, where the pulse effect is dependent on the relatively easily decomposable components, such as POC and EOC (PriemeÂA and Christensen, 2001). After precipitation, water enters the soil, resulting in the destruction of soil aggregates and an increase in the surface area of SOM exposed to soil microbes (Fischer, 2009; Rakhsh et al., 2020). Some studies have shown that alternating wet and dry processes can reduce soil aggregates by $21-30 \%$ and increase soil $\mathrm{CO}_{2}$ release (Denef et al., 2001; $\mathrm{He}$ and $\mathrm{Yu}$, 2016). Therefore, the available substrate accumulated in soils could be quickly decomposed and utilized by soil microbes after soil rewetting, resulting in the observed pulse effect of precipitation. Barnard et al. (2013) demonstrated that, after a drought period, the annual $\mathrm{CO}_{2}$ emissions from annual grasslands in the Mediterranean after rainfall accounted for a large portion of the annual $\mathrm{CO}_{2}$ emissions of the region. According to climate change models, changes in the precipitation 

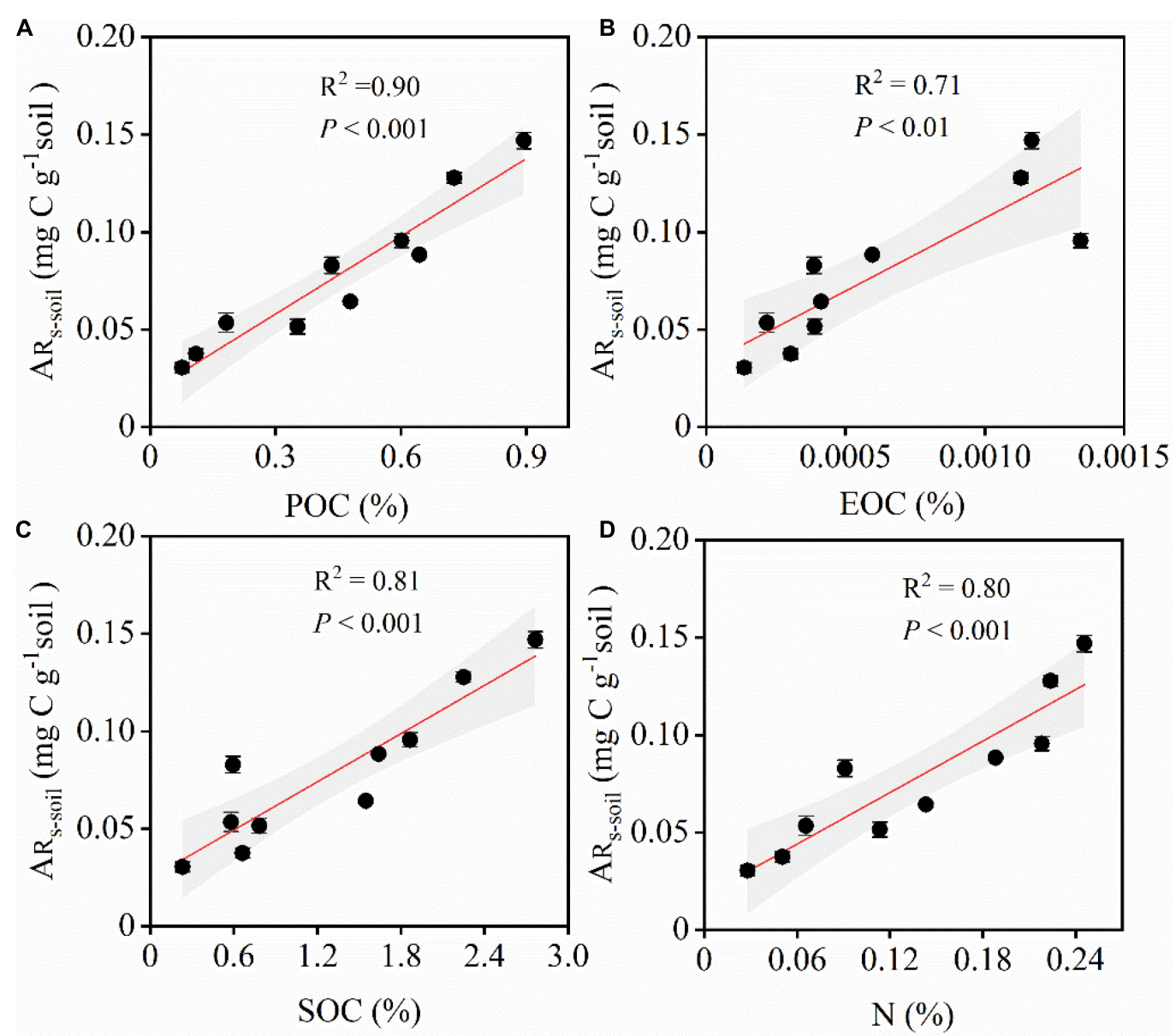

FIGURE 6 | Relationships between $A_{R s-s o i l}$ and environmental factors. $A_{R s-s o i l}$, accumulative emission of $\mathrm{CO}_{2}$ relative to soil (A) Relationships between $A_{R s-s o i l}$ and POC. POC, particulate organic carbon. (B) Relationships between $A_{R s-s o i l}$ and EOC. EOC, easily oxidizable organic carbon. (C) Relationships between $A_{R s-s o i l}$ and SOC. SOC, soil organic carbon. (D) Relationships between $A_{R s-s o i l}$ and N. N, total nitrogen. Shaded areas indicate the $95 \%$ confidence interval and vertical bars denote SE.

status may alter the $R_{s}$ in these pulse-driven ecosystems, thereby altering the $\mathrm{C}$ budget and its relative importance in grassland ecosystems (Huxman et al., 2004a). In the present study, $R_{\text {soil-max }}$ and $A_{R s-s o i l}$ were significantly positively correlated with soil quality, which indicates indicating that the rapid and strong pulse effect in such ecosystem types may be predicted using ecological models.

\section{Soil Microbes Influence the Precipitation Pulse Effect to Some Extent}

Soil microbes are influential factors that directly affect the $R_{s}$ and soil $\mathrm{C}$ cycles. The present study showed that the soil microbial biomass was linearly positively correlated with the accumulated $\mathrm{CO}_{2}\left(A_{R s-\text { soil }}\right)$ (Figure 8). Under normal conditions, bacteria account for more than half of the total microorganisms in steppe soils (Wang et al., 2016b). Under drought conditions, substrate supply is the main limiting factor for soil microbial activity; however, under humid conditions, oxygen diffusion determines soil microbial activity to a large extent, influencing SOM decomposition (Sun et al., 2018). Soil microbes and their cycles are an important source of soil nutrient storage and available nutrients for plant growth and can profoundly affect plant available SOM in terrestrial ecosystems (Sponseller, 2007; Fan et al., 2019). In natural ecosystems, soil microbes are highly sensitive to water conditions, and many species will enter a dormant state under drought stress. Once soil moisture improves, these microbes can quickly become active and multiply (Preece et al., 2019), thereby affecting soil microbial respiration. In Californian grasslands, repeated wet dry alternations induced a seven-fold increase in the number and activity of deep soil microbes, and the number of surface soil microbes increased by only 50\% (Munson et al., 2009). Furthermore, dry-wet alternation can enhance the ratio of fungi to bacteria, and because the decomposition of SOM by fungal and bacterial communities differs, such changes can indirectly affect SOM decomposition. Asynergistic increase in bacterial and fungal abundance under increased rainfall is thought to be responsible for the increase in soil respiration (Mikha et al., 2005). 

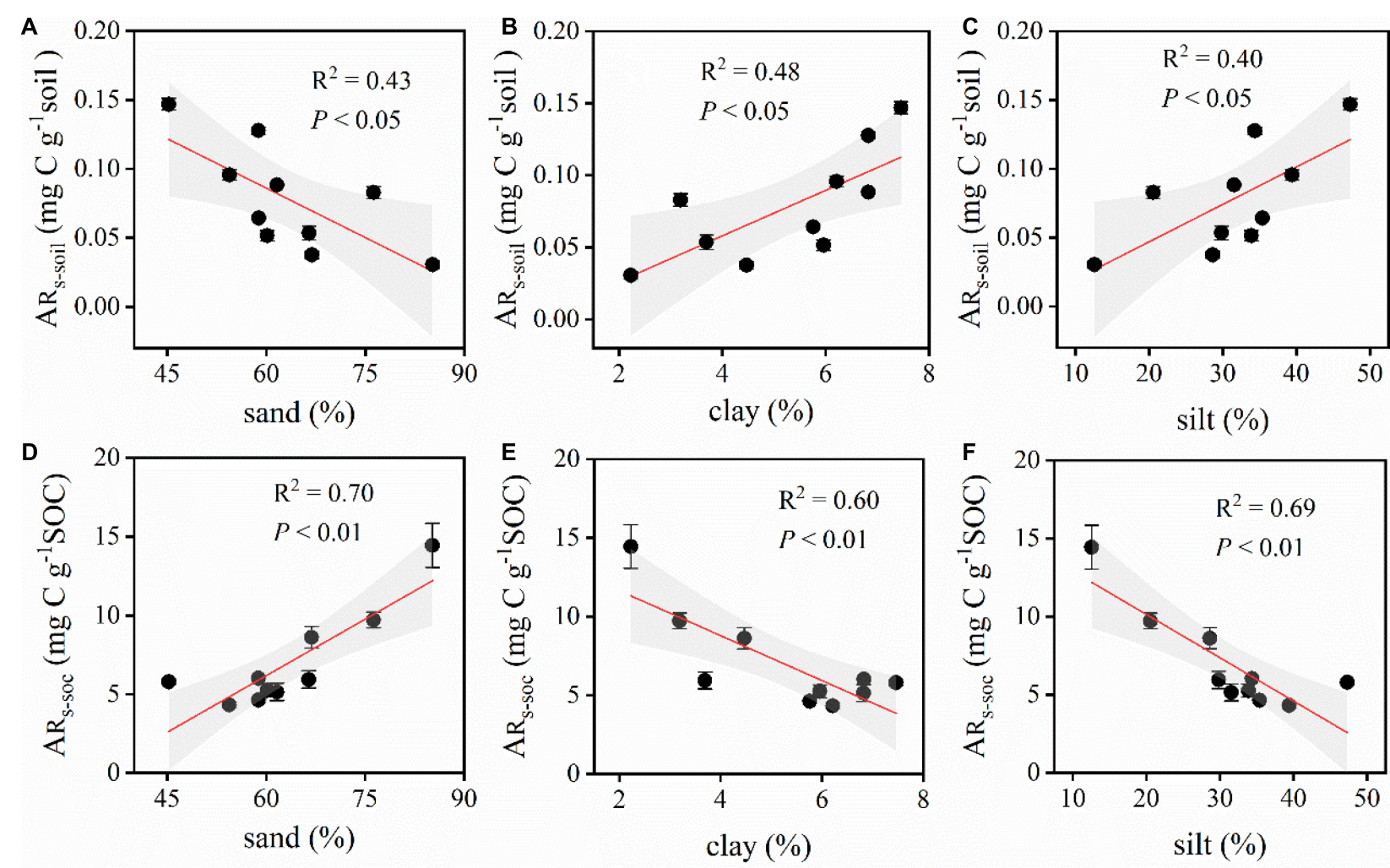

FIGURE 7 | Relationships between $A_{R s-s o i l}, A_{R s-S O C}$, and the different proportions of the soil components. $A_{R s-s o i l}$, accumulative emission of CO 2 relative to soil mass; $A_{R s-S O C}$, accumulative emission of $\mathrm{CO}_{2}$ relative to SOC. (A) Relationships between $A_{R s-\text { soil }}$ and sand. (B) Relationships between $A_{R s-s o i l}$ and clay. (C) Relationships between $A_{R s-s o i l}$ and silt. (D) Relationships between $A_{R s-S O C}$ and sand. (E) Relationships between $A_{R s-S O C}$ and clay. (F) Relationships between $A_{R s-S O C}$ and silt. Shaded areas indicate the 95\% confidence interval and vertical bars denote SE.

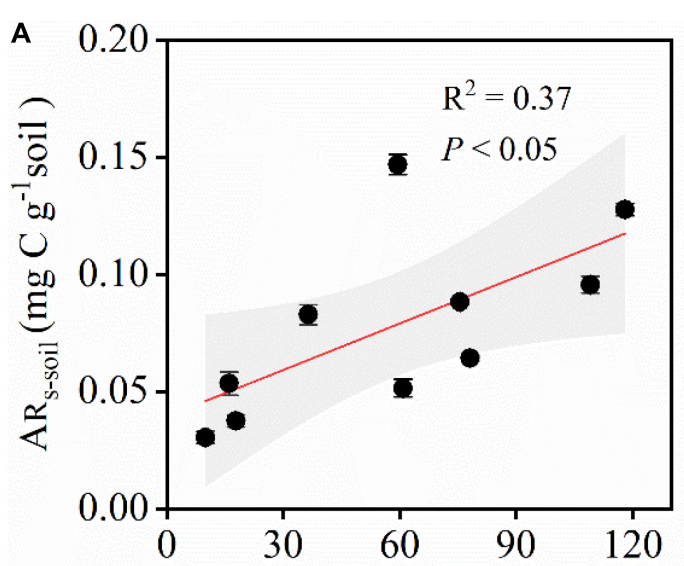

soil microorganism $\left(10^{8} \mathrm{nfu} \mathrm{g}^{-1}\right.$ soil $)$

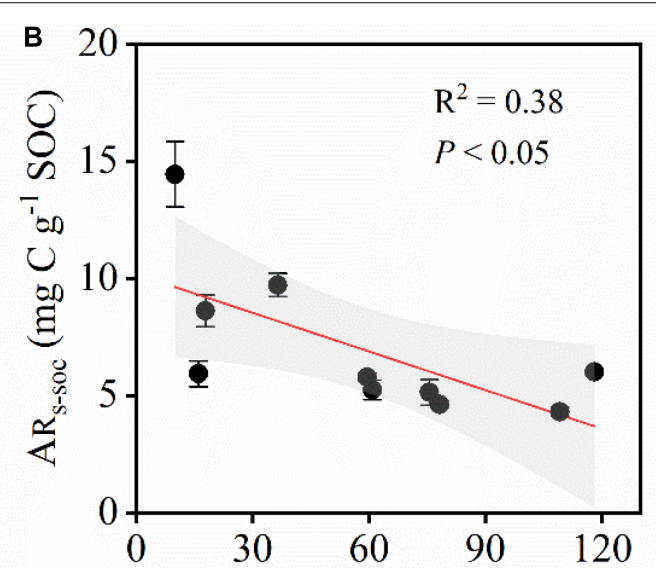

soil microorganism $\left(10^{8} \mathrm{nfu} \mathrm{g}^{-1}\right.$ soil $)$

FIGURE 8 | Relationship between $A_{R s-s o i l}, A_{R s-S O C}$, and the soil microbial biomass. $A_{R s-s o i l}$, accumulative emission of $\mathrm{CO}_{2}$ relative to soil mass; $A_{R s-S O C}$, accumulative emission of $\mathrm{CO}_{2}$ relative to SOC. (A) Relationship between $A_{R s-\text { soil }}$ and the soil microbial biomass. (B) Relationship between $A_{R s-S O C}$ and the soil microbial biomass. Shaded areas indicate the 95\% confidence interval and vertical bars denote SE.

Soil microbes are sensitive to the rapid alteration of soil moisture and may enter a state of dormancy under drought stress. Our research results confirmed this conclusion. After the precipitation event, the rate of microbial respiration, increased several times or even ten times. After an initial increase in mineralization microbial solute diffusion can decreases, resulting 
in a reduction in the SOM decomposition rate (Cui et al., 2019). Our study found a significant positive correlation between microbial biomass and both $A_{R s-s o i l}$ and $A_{R s-S O C}$. As a direct participant in SOM decomposition, the number and community structure of soil microbes directly affects the soil respiration rate and the accumulation of released $\mathrm{CO}_{2}$ (Wang et al., 2016b). When soil moisture rapidly increases after precipitation, these microbes quickly become active and start decomposing SOM. The cumulative amount of $\mathrm{CO}_{2}$ released during the precipitation pulse increased significantly. Accompanied by associated changes in the soil microbial community (Nielsen and Ball, 2015). Precipitation events can, therefore, result in the rapid and drastic release of $\mathrm{CO}_{2}$ within a short period of time (Deng et al., 2018).

\section{CONCLUSION}

In summary, the soils along a precipitation transect in a temperate steppe environment showed strong precipitation pulse effects, i.e., $\mathrm{CO}_{2}$ release was stimulated after the simulation of a precipitation event; however, the responses differed among the different grassland types. Furthermore, the $R_{\text {soil-max }}$ and $A_{R s-s o i l}$ values within $48 \mathrm{~h}$ after the simulated precipitation event, were significantly affected by soil quality, soil particle size, and soil microbial biomass. Furthermore, the precipitation pulse effect, as demonstrated by $R_{\text {soil-max }}$ and $A_{R s-s o i l}$, was positively correlated with soil quality parameters, i.e., SOC, POC, EOC, and $\mathrm{N}$. These results largely support the substrate supply hypothesis for precipitation pulse effects, thus, providing a good perspective to predict these rapid and drastic fluxes, and are based on the measurements of the dynamic changes in substrate content and soil microbial biomass. Our findings verify that soil $\mathrm{CO}_{2}$ release from precipitation events is significant in grasslands in arid and

\section{REFERENCES}

Alba Gutiérrez-Girón, E. D. P., Agustín Rubio, Rosario, G., and Gavilán, R. G. (2015). Both altitude and vegetation affect temperature sensitivity of soil organic matter decomposition in mediterranean high mountain soils. Geoderma 237238, 1-8. doi: 10.1016/j.geoderma.2014.08.005

Appel, T. (1998). Non-biomass soil organic N - the substrate for $\mathrm{N}$ mineralization flushes following soil drying-rewetting and for organic $\mathrm{N}$ rendered $\mathrm{CaCl} 2$ extractable upon soil drying. Soil Biol. Biochem. 30, 1445-1456. doi: 10.1016/ S0038-0717(97)00230-7

Austin, A. T., Yahdjian, L., Stark, J. M., Belnap, J., Porporato, A., Norton, U., et al. (2004). Water pulses and biogeochemical cycles in arid and semiarid ecosystems. Oecologia 141, 221-235. doi: 10.1007/s00442004-1519- 1

Bååth, E., and Anderson, T. H. (2003). Comparison of soil fungal/bacterial ratios in a $\mathrm{pH}$ gradient using physiological and PLFA-based techniques. Soil Biol. Biochem. 35, 955-963. doi: 10.1016/s0038-0717(03)00154-8

Bai, Y., Wu, J., Xing, Q., Pan, Q., Huang, J., Yang, D., et al. (2008). Primary production and rain use efficiency across a precipitation gradient on the mongolia plateau. Ecology 89, 2140-2153. doi: 10.1890/07-0992.1

Barnard, R. L., Osborne, C. A., and Firestone, M. K. (2013). Responses of soil bacterial and fungal communities to extreme desiccation and rewetting. ISME J. 7, 2229-2241. doi: 10.1038/ismej.2013.104

Birch, H. F. (1958). The efffect of soil drying on humus decomposition and nitrogen availability. Plant Soil 10, 9-31. doi: 10.1007/bf01343734 semi-arid regions and, provide new insights for ecological models to simulate ecosystem $\mathrm{C}$ cycle responses in these regions under future climate change scenarios.

\section{DATA AVAILABILITY STATEMENT}

The original contributions presented in the study are included in the article/Supplementary Material, further inquiries can be directed to the corresponding author/s.

\section{AUTHOR CONTRIBUTIONS}

$\mathrm{NH}, \mathrm{HB}$, and ZJ designed the experiments and wrote the manuscript. ZJ and NH conducted the experiments and analyzed the data. LX and ML revised the manuscript. All authors contributed to the article and approved the submitted version.

\section{FUNDING}

This work was supported by the National Natural Science Foundation of China (31988102 and 31870437), The second Tibetan Plateau Scientific Expedition and Research Program (STEP, 2019QZKK060602), and the Chinese Academy of Sciences Strategic Priority Research Program (XDA23080401).

\section{SUPPLEMENTARY MATERIAL}

The Supplementary Material for this article can be found online at: https://www.frontiersin.org/articles/10.3389/fevo.2021. 673310/full\#supplementary-material

Cao, Y., Wu, Z., and Ke, L. (2010). Vegetation change in northeast china transect from 2000 to 2008. Quat. Res 30, 531-539. doi: 10.3969/j.issn.1001-7410.2010. 03.11

Chen, S., Lin, G., Huang, J., and He, M. (2008). Responses of soil respiration to simulated precipitation pulses in semiarid steppe under different grazing regimes. J. Plant Ecol. 1, 237-246. doi: 10.1093/jpe/rtn020

Craine, J. M., Fierer, N., McLauchlan, K. K., and Elmore, A. J. (2012). Reduction of the temperature sensitivity of soil organic matter decomposition with sustained temperature increase. Biogeochemistry 113, 359-368. doi: 10.1007/s10533-0129762-8

Cui, Y., Fang, L., Deng, L., Guo, X., Han, F., Ju, W., et al. (2019). Patterns of soil microbial nutrient limitations and their roles in the variation of soil organic carbon across a precipitation gradient in an arid and semi-arid region. Sci. Total Environ. 658, 1440-1451. doi: 10.1016/j.scitotenv.2018.12.289

Davidson, E. A., Verchot, L. V., Cattanio, J. H., Ackerman, I. L., and Carvalho, J. E. M. (2000). Effects of soil water content on soil respiration in forests and cattle pastures of eastern Amazonia. Biogeochemistry 48, 53-69. doi: 10.1023/A: 1006204113917

Denef, K., Six, J., Bossuyt, H., Freya, S. D., Elliott, E. T., Merckx, R., et al. (2001). Influence of dry-wet cycles on the interrelationship between aggregate, particulate organic matter, and microbial community dynamics. Soil Biol. Biochem. 33, 1599-1611. doi: 10.1016/S0038-0717(01)00076-1

Deng, Q., Zhang, D., Han, X., Chu, G., Zhang, Q., and Hui, D. (2018). Changing rainfall frequency rather than drought rapidly alters annual soil respiration in a tropical forest. Soil Biol. Biochem. 121, 8-15. doi: 10.1016/j.soilbio.2018.02.023 
Esch, E. H., Lipson, D., and Cleland, E. E. (2016). Direct and indirect effects of shifting rainfall on soil microbial respiration and enzyme activity in a semi-arid system. Plant Soil 411, 333-346. doi: 10.1007/s11104-016-3027-6

Fan, Y., Li, Y., and Li, Q. (2019). Microbe, enaymatic activity and nutrient contents of soil in different stand ages of Pinus tabuliformis. Res. Soil Water Conserv. 6, 58-64. doi: 1005-3409(2019)06-0058-07

Fang, J., Yang, Y., Ma, W., Mohammat, A., and Shen, H. (2010). Ecosystem carbon stocks and their changes in China's grasslands. Sci. China Life Sci. 53, 757-765. doi: 10.1007/s11427-010-4029-x

Fischer, T. (2009). Substantial rewetting phenomena on soil respiration can be observed at low water availability. Soil Biol. Biochem. 41, 1577-1579. doi: 10. 1016/j.soilbio.2009.04.009

Fowler, D., Coyle, M., Skiba, U., Sutton, M. A., Cape, J. N., Reis, S., et al. (2013). The global nitrogen cycle in the twenty-first century. Philos. Trans. R. Soc. Lond. B Biol. Sci. 368:20130164. doi: 10.1098/rstb.2013.0164

Göransson, H., Godbold, D. L., Jones, D. L., and Rousk, J. (2013). Bacterial growth and respiration responses upon rewetting dry forest soils: Impact of droughtlegacy. Soil Biol. Biochem. 57, 477-486. doi: 10.1016/j.soilbio.2012.08.031

He, N., Wang, R., Gao, Y., Dong, J., Wen, X., and Yu, G. (2013). Changes in the temperature sensitivity of SOM decomposition with grassland succession: implications for soil C sequestration. Ecol. Evol. 3, 5045-5054. doi: 10.1002/ ece3.881

He, N., Wu, L., Wang, Y., and Han, X. (2009). Changes in carbon and nitrogen in soil particle-size fractions along a grassland restoration chronosequence in northern China. Geoderma 150, 302-308. doi: 10.1016/j.geoderma.2009.02.004

$\mathrm{He}, \mathrm{N}$., and $\mathrm{Yu}, \mathrm{G}$. (2016). Stoichiometrical regulation of soil organic matter decomposition and its temperature sensitivity. Ecol. Evol. 6, 620-627. doi: 10. 1002/ece3.1927

Huxman, T. E., Cable, J. M., Ignace, D. D., Eilts, J. A., English, N. B., Weltzin, J., et al. (2004a). Response of net ecosystem gas exchange to a simulated precipitation pulse in a semi-arid grassland: the role of native versus nonnative grasses and soil texture. Oecologia 141, 295-305. doi: 10.1007/s00442003-1389-y

Huxman, T. E., Snyder, K. A., Tissue, D., Leffler, A. J., Ogle, K., Pockman, W. T., et al. (2004b). Precipitation pulses and carbon fluxes in semiarid and arid ecosystems. Oecologia 141, 254-268. doi: 10.1007/s00442-0041682-4

Jones, D. L., and Murphy, D. V. (2007). Microbial response time to sugar and amino acid additions to soil. Soil Biol. Biochem. 39, 2178-2182. doi: 10.1016/j.soilbio. 2007.03.017

Kang, L., Han, X., Zhang, Z., and Sun, O. J. (2007). Grassland ecosystems in China: review of current knowledge and research advancement. Philo.s Trans. R. Soc. Lond. B Biol. Sci. 362, 997-1008. doi: 10.1098/rstb.2007.2029

Koch, G. W. (1995). Terrestrial transects for global change research. Global Change and Terrestrial Ecosystems in Monsoon Asia. 53-65. doi: 10.1007/978-94-0110343-5_6

Lee, M. S., Nakane, K., Nakatsubo, T., Mo, W. H., and Koizumi, H. (2002). Effects of rainfall events on soil $\mathrm{CO} 2$ flux in a cool temperate deciduous broad-leaved fores. Ecol. Res. 17, 401-409. doi: 10.1046/j.1440-1703.2002. 00498.x

Li, X., Zhao, Y., Yang, H., Zhang, P., and Gao, Y. (2018). Soil respiration of biologically-crusted soils in response to simulated precipitation pulses in the tengger desert, Northern China. Pedosphere 28, 103-113. doi: 10.1016/s10020160(17)60307-2

Liu, X. D., Qiao, Y.-N., and Zhou, G. Y. (2011). Controlling action of soil organic matter on soil moisture retention and its availability. Chin. J. Plant Ecol. 35, 1209-1218. doi: 10.3724/sp.j.1258.2011.01209

Liu, Y., He, N., Wen, X., Xu, L., Sun, X., Yu, G., et al. (2018). The optimum temperature of soil microbial respiration: patterns and controls. Soil Biol. Biochem. 121, 35-42. doi: 10.1016/j.soilbio.2018.02.019

Mayes, M. A., Heal, K. R., Brandt, C. C., Phillips, J. R., Jardine, P. M., Melani, A., et al. (2012). Relation between soil order and sorption of dissolved organic carbon in temperate subsoils. Soil Sci. Soc. Am. J. Am. J. 76, 1027-1037. doi: $10.2136 /$ sssaj

Mikha, M. M., Rice, C. W., and Milliken, G. A. (2005). Carbon and nitrogen mineralization as affected by drying and wetting cycles. Soil Biol. Biochem. 37, 339-347. doi: 10.1016/j.soilbio.2004.08.003

Moyano, F. E., Manzoni, S., and Chenu, C. (2013). Responses of soil heterotrophic respiration to moisture availability: an exploration of processes and models. Soil Biol. Biochem. 59, 72-85. doi: 10.1016/j.soilbio.2013.01.002
Müller, T., and Höper, H. (2004). Soil organic matter turnover as a function of the soil clay content: consequences for model applications. Soil Biol. Biochem. 36, 877-888. doi: 10.1016/j.soilbio.2003.12.015

Munson, S. M., Benton, T. J., Lauenroth, W. K., and Burke, I. C. (2009). Soil carbon flux following pulse precipitation events in the shortgrass steppe. Ecol. Res. 25, 205-211. doi: 10.1007/s11284-009-0651-0

Najera, F., Dippold, M. A., Boy, J., Seguel, O., Koester, M., Stock, S., et al. (2020). Effects of drying/rewetting on soil aggregate dynamics and implications for organic matter turnover. Biol. Fertil. Soils 56, 893-905. doi: 10.1007/s00374020-01469-6

Nelson, D. W., and Sommers, L. E. (1982). Total carbon, organic carbon, and organic matter, methods of soil analysis. Methods Soil Anal. 34, 961-1010. doi: 10.2136/sssabookser5.3.c34

Ni, X., Liao, S., Wu, F., and Groffman, P. M. (2019). Short-term precipitation pulses stimulate soil $\mathrm{Co}_{2}$ emission but do not alter $\mathrm{CH} 4$ and $\mathrm{N} 2 \mathrm{O}$ fluxes in a northern hardwood forest. Soil Biol. Biochem. 130, 8-11. doi: 10.1016/j.soilbio.2018.11. 021

Nielsen, U. N., and Ball, B. A. (2015). Impacts of altered precipitation regimes on soil communities and biogeochemistry in arid and semi-arid ecosystems. Glob. Chang. Biol. 21, 1407-1421. doi: 10.1111/gcb.12789

Norton, U., Mosier, A. R., Morgan, J. A., Derner, J. D., Ingram, L. J., and Stahl, P. D. (2008). Moisture pulses, trace gas emissions and soil $\mathrm{C}$ and $\mathrm{N}$ in cheatgrass and native grass-dominated sagebrush-steppe in Wyoming. U.S.A.Soil Biol. Biochem. 40, 1421-1431. doi: 10.1016/j.soilbio.2007.12.021

Preece, C., Verbruggen, E., Liu, L., Weedon, J. T., and Peñuelas, J. (2019). Effects of past and current drought on the composition and diversity of soil microbial communities. Soil Biol. Biochem. 131, 28-39. doi: 10.1016/j.soilbio.2018.12.022

PriemeÂ, A., and Christensen, S. (2001). Natural perturbations, drying-wetting and freezing-thawing cycles, and the emission of nitrous oxide, carbon dioxide and methane from farmed organic soils. Soil Biol. Biochem. 33, 2083-2091. doi: 10.1016/S0038-0717(01)00140-7

Rakhsh, F., Golchin, A., Beheshti, A. A. A., and Nelson, P. N. (2020). Mineralization of organic carbon and formation of microbial biomass in soil: effects of clay content and composition and the mechanisms involved. Soil Biol. Biochem. 151:108036. doi: 10.1016/j.soilbio.2020.108036

Schlesinger, W. H., and Andrews, J. A. (2000). Soil respiration and the global carbon cycle. Biogeochemistry 48, 7-18. doi: 10.1023/A:1006247623877

Smith, A. P., Bond-Lamberty, V. L., Benscoter, B. W., Tfaily, M. M., Hinkle, T. C., Liu, C., et al. (2017). Shifts in pore connectivity from precipitation versus groundwater rewetting increases soil carbon loss after drought. Nat. Commun. 8:1335. doi: 10.1038/s41467-017-01320-x

Song, S., Jing, C., and $\mathrm{Hu}, \mathrm{Z}$. (2017). Opposite trends in light rain days over western and eastern China from 1960 to 2014. Atmosphere 8:54. doi: 10.3390/ atmos 8030054

Sponseller, R. A. (2007). Precipitation pulses and soil CO2 flux in a Sonoran Desert ecosystem. Glob. Chang. Biol. 13, 426-436. doi: 10.1111/j.1365-2486. 2006.01307.x

Stark, J. M., and Firestone, M. K. (1995). Mechanisms for Soil moisture effects on activity of nitrifying bacteria. Appl. Environ. Microbiol. 61, 218-221. doi: 10.1021/bk-1995-0604.ch011

Sun, Q., Meyer, W. S., and Marschner, P. (2018). Repeated rainfall in summer induces prolonged high soil respiration in a semi-arid floodplain woodland. Ecohydrology 11:e1984. doi: 10.1002/eco.1984

Wang, Q., He, N., Liu, Y., Li, M., and Xu, l (2016a). Strong pulse effects of precipitation events on soil microbial respiration in temperate forests. Geoderma 275, 67-73. doi: 10.1016/j.geoderma.2016.04.016

Wang, Q., He, N., Yu, G., Gao, Y., Wen, X., Wang, R., et al. (2016b). Soil microbial respiration rate and temperature sensitivity along a north-south forest transect in eastern China: patterns and influencing factors. J. Geophys. Res. Biogeosci. 121, 399-410. doi: 10.1002/2015jg003217

Wang, Y., Wang, H., Ma, Z., Li, Q., and Xu, F. (2010). Review of response mechanism of soil respiration to rainfall. Chin. J. Plant Ecol. 34, 601-610. doi: 10.3773/j.issn.1005-264x.2010.05.014

Wu, J., and Brookes, P. C. (2005). The proportional mineralisation of microbial biomass and organic matter caused by air-drying and rewetting of a grassland soil. Soil Biol. Biochem. 37, 507-515. doi: 10.1016/j.soilbio.2004.07.043

Xiang, S. R., Doyle, A., Holden, P. A., and Schimel, J. P. (2008). Drying and rewetting effects on $\mathrm{C}$ and $\mathrm{N}$ mineralization and microbial activity in surface and subsurface California grassland soils. Soil Biol. Biochem. 40, 2281-2289. doi: 10.1016/j.soilbio.2008.05.004 
Xu, L., Baldocchi, D. D., and Tang, J. (2004). How soil moisture, rain pulses, and growth alter the response of ecosystem respiration to temperature. Global biogeochem. Cycles 18:GB4002. doi: 10.1029/2004gb002281

Xu, Z., Yu, G., Zhang, X., Ge, J., He, N., Wang, Q.,et al. (2015). The variations in soil microbial communities, enzyme activities and their relationships with soil organic matter decomposition along the northern slope of Changbai Mountain. Appl. Soil Ecol. 86, 19-29. doi: 10.1016/j.apsoil.2014.09.015

Zhu, C., Ma, Y., Wu, H., Sun, T., La Pierre, K. J., Sun, Z., et al. (2016). Divergent effects of nitrogen addition on soil respiration in a semiarid grassland. Sci. Rep. 6:33541. doi: $10.1038 /$ srep33541
Conflict of Interest: The authors declare that the research was conducted in the absence of any commercial or financial relationships that could be construed as a potential conflict of interest.

Copyright (c) 2021 Jiang, Bian, Xu, Li and He. This is an open-access article distributed under the terms of the Creative Commons Attribution License (CC BY). The use, distribution or reproduction in other forums is permitted, provided the original author(s) and the copyright owner(s) are credited and that the original publication in this journal is cited, in accordance with accepted academic practice. No use, distribution or reproduction is permitted which does not comply with these terms. 